dave winfield, who picks up about

a mil a year from the damn yankees, explained his less than virtuoso

option year with the padres.

what was the point of diving

for fly balls when there were only

a few thousands fans in the stands?

also why chance a broken leg

and an amputated bonus?

when he got to the Big Apple

it would be different,

and to an extent it has.

Joe DiMaggio once belly-flopped

for a blooper during the exhibition grind.

asked why he risked livelihood and $1 \mathrm{imb}$

during such a nothing game, DiMag replied:

"some kid might be watching."

of course, DiMag was not worth winfield's weight

in bucks. after Joe $\mathrm{Di}^{\prime}$ 's streak year of ' 56 , colonel jake refused his request for a raise.

\title{
LITERATURE AND BIOGRAPHY
}

anecdotes, purportedly illustrative, $i$ tendered one from my past to bring into real world relief the naturalism of Long Day's Journey Into Night,

in which the four Tyrones are determined

by the foggy patterns of their past.

the father, once bone-poor, but now secure, still cannot wave an open wallet.

like my mother, a depression-bride, who during the mild prosperity of WW II garnered a respectable rack of garmets but wore them only for church and bridge, dressed like a bag-lady til the day she died.

a co-ed raised her hand and without a shred of irony asked:

"does that mean you have a

closetful of dresses at home?"

two anecdotes are better than one. 